\title{
Kjøtt sett i relasjon til evolusjonen
}

\author{
Diskusjonen om hvorvidt rødt kjøtt er helseskadelig er preget av uvitenskapelige ytterligheter. Uenighet \\ og forvirringer er fremtredende. Evolusjonen baserer seg på naturvitenskapelig forskning. Kan den brukes \\ som en logisk forklaringsmodell?
}

Verdens helseorganisasjon (WHO) konkluderer med at bearbeidet kjøtt og rødt kjøtt kan fremkalle kreft i tykktarmen (1).

I Tidsskriftet nr. 8/2016 (2) skrev Tetyana Kalchenko, som leder for foreningen Helsepersonell for plantebasert kosthold (HePla), en artikkel med overskriften Gammeldags og feil om kjøttfri kost (2). Dette var bl.a. en kritikk av et tidligere innlegg i Tidsskriftet av gjesteskribent, kokk og forfatter Andreas Viestad med tittelen Antidietten, hvor han ufarliggjør kjøttet (3).

I etterkant av en internasjonal workshop i Oslo i november 2013 publiserte alle foredragsholderne en felles «state of the art»artikkel i tidsskriftet Meat Science (4). Det er vanskelig å finne sikre forskjeller i forekomst av tarmkreft hos vegetarianere og kjøttspisere. Det er vist at samer som spiser mye rødt reinsdyrkjøtt, har lavere forekomst av tarmkreft enn referansepopulasjonen fra samme region. Lav forekomst foreligger også i de fleste afrikanske land og i det sørlige og sentrale Asia. Kreft er en livsstilssykdom spesielt i de vestlige land. Overvekt og manglende fysisk aktivitet kan derfor være en vesentlig faktor (4). Forskningen på sammenhengen mellom rødt kjøtt og tarmkreft er altså uklar og til dels motstridende.

Det er tilsynelatende vanskelig å skille mellom hva som er uvitenskapelig og naturvitenskapelig kunnskap. Evolusjonen er et fagfelt med basis i den største naturvitenskapelige forskningen. Evolusjonen er derfor ikke noe du tror på, det er noe du forstår. Inntak av en viss mengde av et næringsstoff kan defineres som optimal. Både et større og et mindre inntak enn det optimale kan gi økt risiko for visse sykdommer (5). Det er blitt hevdet at det eksisterer en optimalt sammensatt kost for alle levende arter bestemt av artens genetiske arv. Løven er programmert til å spise bare animalsk føde, mens antilopen er programmert til å ernære seg av planter. Menneskets genetiske program, som har vært relativt uforandret gjennom 100000 år, er tilpasset blandet naturlig føde, men ikke ferdigprodusert mat (5). Bearbeidet animalsk føde har en meget kort historie, men utgjør i dag hoveddelen av moderne menneskers næringsinntak. Mennesker har ikke et genetisk program som uten omkostninger kan omsette moderne tilsetningsstoffer. Det er nærliggende å anta at dette kan overbelaste kroppen og være sykdomsfremkallende (6).

\section{Programmert for annen livsstil}

Evolusjon er en stadig genetisk omprogrammering, dels ved tilfeldige permanente muta- sjoner som kan påvirke organismens evne til å overleve og reprodusere seg selv.

Mutasjon er en genetisk prøving og feiling og «overtar», dvs. endringen føres videre, om den er bedre enn utgangspunktet. Det

\section{«Våre gener er fanget i et metabolsk fengsel designet av evolusjonen»}

skjer også ikke-permanente og overfladiske, såkalte epigenetiske programendringer som er miljøutløst - vellykket eller ikke vellykket. Et eksempel er at befolkninger fra mindre urbaniserte miljøer som utsettes for et mer «moderne» vestlig kosthold, lettere får livsstilssykdommer, jf. Barker-hypotesen (7)

For 100000 år siden måtte maten hentes. Frukt, grønt, animalsk føde og fisk var tilgjengelig gjennom jakt og fiske, dvs. det vi i dag definerer som utholdende fysisk aktivitet. Vårt genetiske program gjennom tilfeldige mutasjoner er tilpasset dette. De som ikke hadde denne programendringen, døde ut. Uten disse feilene ville ingen ting utvikle seg. Vårt genetiske program er derfor tidsmessig fortsatt tilpasset tiden fra menneskets opprinnelse, både hva gjelder næringsinntak og fysisk aktivitet. Dette ser vi tydelig gjennom nyere epigenetisk forskning som viser gunstige endringer ved fysisk utholdenhetstrening, en slags reparasjon av gener skadet av livsstilen, med risiko for utvikling av diabetes, hjerteog karsykdommer og kreft (8). Man kan si at våre gener er fanget $i$ et metabolsk fengsel designet av evolusjonen, tilpasset 100000 år med naturlig føde kombinert med jakt og fiske.

Hva med maten? Frukt, grønt og ren fisk uten fargestoffer og koksalttilsetninger er akseptert. Bearbeidet kjøtt tilsatt salt, nitrat, nitritt eller andre tilsetningsstoffer er sterkt knyttet til kreft. Verdens helseorganisasjon mener at epidemiologiske studier viser en direkte sammenheng mellom bearbeidet kjøtt og tarmkreft (1).

Hva så med rent, rødt kjøtt? Fra menneskets opprinnelse har dette vært den viktigste delen av næringskjeden. I henhold til evolusjonen har vårt genetiske program utviklet en sykdomsbeskyttende funksjon, men bestemt ut fra andre forutsetninger enn i dag.
Verdens helseorganisasjon har usikre data på direkte sammenheng mellom tarmkreft og rent, rødt kjøtt. Ut fra forandringer på genenes DNA og biokjemisk belastning har de bare et indirekte og usikkert bevis (1).

Spørsmålet kan være om tapt fysisk aktivitet er den variabelen som er årsaken til eventuelle skadevirkninger. Om man ønsker å studere biologiske effekter av trening, kan man ikke studere effekten av fysisk aktivitet alene, men man må se på effekten av reintroduksjon av trening i en usunn stillesittende populasjon som generelt sett er programmert for fysisk aktivitet. Det vises her til studier av effekten av utholdenhetstrening på livsstilssykdommer, herunder kreft $(8,9)$.

\section{Tor-Erik Widerøe \\ tor-erik.wideroe@ntnu.no}

Tor-Erik Widerøe (f. 1940) er professor emeritus ved Institutt for kreftforskning og molekylær medisin, Norges teknisk-naturvitenskapelige universitet.

Forfatter har fylt ut ICMJE-skjemaet og oppgir ingen interessekonflikter.

Litteratur

1. Bouvard V, Loomis D, Guyton KZ et al. Carcinogenicity of consumption of red and processed meat. Lancet Oncol 2015; 16: 1599-600.

2. Kalchenko T. Gammeldags og feil om kjøttfri kost. Tidsskr Nor Legeforen 2016; 136: 698.

3. Viestad A. Antidietten. Tidsskr Nor Legeforen 2016; $136: 500$.

4. Oostindjer M, Alexander J, Amdam GV et al. The role of red and processed meat in colorectal cancer development: a perspective. Meat Sci 2014; 97 : 583-96.

5. Eaton SB, Konner M. Paleolithic nutrition. A consideration of its nature and current implications. N Engl J Med 1985; 312: 283-9.

6. Karppanen H, Karppanen P, Mervaala E. Why and how to implement sodium, potassium, calcium, and magnesium changes in food items and diets? J Hum Hypertens 2005; 19 (suppl 3): S10-9.

7. Holmboe-Ottesen G. Globale trender i matkonsum og ernaering. Tidsskr Nor Lægeforen 2000; 120: $78-82$.

8. Ntanasis-Stathopoulos J, Tzanninis J-G, Philippou A et al. Epigenetic regulation on gene expression induced by physical exercise. J Musculoskelet Neuronal Interact 2013; 13: 133-46.

9. Voisin S, Eynon N, Yan X et al. Exercise training and DNA methylation in humans. Acta Physiol (Oxf) 2015; 213: 39-59.

Mottatt 8.8. 2016, første revisjon innsendt 24.8. 2016, godkjent 25.8. 2016. Redaktør: Ketil Slagstad.

Publisert først på nett. 